\title{
INTEGRATED FARMING MODEL OF SMALL RUMINANTS IN DELI SERDANG, NORTH SUMATRA - INDONESIA
}

\author{
T. A. Kusumastuti ${ }^{1}$, Sarim $^{2}$ and Masyhuri ${ }^{3}$ \\ ${ }^{1}$ Faculty of Animal Science, Gadjah Mada University, \\ Jl. Fauna, Bulaksumur Campus, Yogyakarta - Indonesia \\ ${ }^{2}$ Faculty of Agriculture, Pancabudi University, \\ Jl. Gatot Subroto, Medan - Indonesia \\ ${ }^{3}$ Faculty of Agriculture, Gadjah Mada University, \\ Jl. Flora, Bulaksumur Campus, Yogyakarta - Indonesia \\ Corresponding E-mail : triaksp@yahoo.co.id
}

Received December 13, 2013; Accepted November 19, 2014

\begin{abstract}
ABSTRAK
Penelitian ini bertujuan untuk mengukur nilai tambah ternak kambing dan domba dengan sistem pemberian pakan cut and carry dan faktor-faktor yang mempengaruhi produktivitas ternak serta nilai tambah pemanfaatan kotoran untuk produktivitas tanaman. Penelitian dilakukan di Kabupaten Deli Serdang dengan menentukan dua kecamatan sebagai lokasi penelitian yaitu Kecamatan Tanjung Morawa dan Kecamatan Bangun Purba. Penentuan lokasi dilakukan secara purposive sampling berdasarkan populasi ternak ruminansia kecil dan luas perkebunan sawit yang terdapat di dua kecamatan tersebut. Sampel yang diambil sebanyak 100 sampel terdiri dari 50 responden peternak kambing dan 50 peternak domba yang ada di areal perkebunan kelapa sawit. Hasil penelitian menunjukkan bahwa rata-rata pemilikan kambing di lokasi penelitian sebanyak 18 sampai 24 ekor. Penampilan reproduksi kambing dan domba mendekati rata-rata secara umum. Jumlah induk, pakan dari kelapa sawit dan tanaman sela, jenis ternak dan lokasi berpengaruh sangat nyata terhadap produktivitas ternak $(\mathrm{P}<0,01)$. Kambing menyumbang kotoran sebanyak 16,86 \% dan 11,26\% dari total pohon kelapa sawit yang ada di Tanjung Murawa dan Bangun Purba, sedangkan domba menyumbang kotoran 21,49\% dan 22,56 \% dari total pohon kelapa sawit. Untuk meningkatkan produktivitas tanaman dan ternak maka disarankan untuk menambah populasi ternak, meningkatkan teknologi dan diversifikasi usaha melalui kerjasama dengan badan pemerintah, perguruan tinggi dan swasta.
\end{abstract}

Kata kunci :ruminansia kecil, model integrated farming

\begin{abstract}
This research was done to measure the added value of goat and sheep with cut and carry system and influencing factors of goat/sheep productivity and to measure the added value of manure to palm productivity. The research was done in Deli Serdang Regency by determining two districts as research area: Tanjung Morawa District and Bangun Purba District. Location was determined by purposive sampling technique based on population of small ruminants and area of oil palm plantation in both districts. Sample consisted of 50 goat farmers and 50 sheep farmers. Results indicated that farmers have 18 to 24 heads of goats or sheep. Performance of goat and sheep reproduction tended to similar to genereral performance. Amount of doe, feed from palm oil and intercropped plant, livestock type and location influence significantly at livestock productivity $(\mathrm{P}<0.01)$. Goat contributed manure $16.86 \%$ and $11.26 \%$ of total palm trees in Tanjung Morawa and Bangun Purba, respectively, while sheep contributed manure $21.49 \%$ and $22.56 \%$ of total palm trees, respectively. Therefore, it was necessary to increase population of livestock, to increase technology and diversification of production. It may be done by
\end{abstract}


establishing partnership with local government, animal of science office and private corporation . Keywords: small ruminants, integrated farming model

\section{INTRODUCTION}

The application of integrated farming system was reported in four models Soedjana (2007), such as the system which is 1) naturally originated from farmers heritage in the local area, 2) only crops without animals involved, 3) mix-farming system between crops and animals and 4) the system which is basically from natural resources, man power and fund. An integrated farming concept with the involvement of livestock and plants are potential alternative to support the development of livestock in Indonesia (Gunawan and Sulastiyah, 2010).

Small ruminant as indigenous livestock support greatly the availability of national meat due to its easily reared and supported by natural resource and Indonesian climate condition particularly feed available in oil palm plantation and by product of oil palm that can be made as quality feed (Manurung, 2004).

Deli Serdang Regency is production centre for small ruminant in North Sumatera Province. In addition, there is alternative feed sources from palm plantation in the regency. Goat and sheep in Deli Serdang Regency grew from year to year. Population of domestic goat in 2008 was 166,964 heads and in 2013 it reached 226,172 heads, while sheep in 2008 was 80,487 heads and in 2013 was 120,721 heads (Dinas Pertanian Kabupaten Deli Serdang, 2013). Area of palm plantation in Deli Serdang Regency was 2,754 ha immature plants and 11,613.60 ha crop yield productive with total production of 192,102.50 ton per year (Dinas Pertanian Kabupaten Deli Serdang, 2012). The regency had expected to be able to meet feed need standard for goat and sheep, and its manure can be used as fertilizer (nutrition element) required by palm plant to produce.

Livestock rearing in palm plantation area used cut-and-carry (intencive system) and extensive system in which cattle is released in palm plant area. When livestock is released to look for feed in palm area, it may damage palm before harvested. In cut and carry system, small ruminants are kept in stall, and feeds are supplied. This system do not give negative impact on main commodity either grass or palm harvest.

Effort to develop goat and sheep should consider quality standard of management. Today the standard weight of yearling small ruminant is $35-45 \mathrm{~kg}$. The obstacle is that the standard weight is difficult to obtain and there is not continuous livestock supply. Goat and sheep have only 20-30 $\mathrm{kg}$ of body weight. Although some of small ruminants meeting the standard, it is very few, so they should be imported from abroad. Therefore, it is necessary doing research on small ruminants productivity measured from added value of livestock and its by product.

\section{MATERIALS AND METHODS}

The research was done in Tanjung Morawa District and Bangun Purba District. Location was determined using purposive sampling method based on small ruminants' population and oil palm plantation area in both districts. In addition there are small ruminants reared with cut and carry system (intensive system) and non cut and extensive system with average ownership of 5 heads.

Basic method used was descriptive method that emphasize on solving actual problem found in current time (Singarimbun and Effendi, 1995). Sample consisted of 50 goat farmers and 50 sheep farmers existing in oil palm plantation.

Added value of small ruminants with cut and carry system was analyzed descriptively with table analysis. Local potential of goat and sheep include composition of animal owned (male, female, kid), livestock reproduction appearance, mating method, age at first kidding (month), kidding interval (month), litter size, age of first mating, mortality rate, non lactation period, and long time of raising (male and female).

To identify factors influencing goat and sheep productivity in two research, the research used multiple regression model with Ordinary Least Square (Gujarati, 2003) model as follow:

$Y_{\mathrm{pr}}=\beta_{0}+\beta_{1} X_{1}+\beta_{2} X_{2}+\beta_{3} X_{3}+\beta_{4} X_{4}+\beta_{5} X_{5}+$ $\mathrm{D}_{1}+\mathrm{D}_{2}+\mu$

$\mathrm{Y}_{\mathrm{pr}}=$ productivity of goat or sheep $(\mathrm{kg} / \mathrm{head})$

$\beta_{0}=$ intercept

$\beta_{1}, \ldots, \beta_{4}=$ regression coefficient

$X_{1}=$ number of doe (head)

$\mathrm{X}_{2}=$ kidding / lambing interval (month)

$\mathrm{X}_{3}=$ litter size (head)

$\mathrm{X}_{4}=$ mortality (head/year) 
$\mathrm{X}_{5}=$ fed from oil palm and intercropped plant $(\mathrm{kg})$

$\mathrm{D}_{1}=$ ruminants type

sheep $=1$

goat $=0$

$\mathrm{D}_{2}=$ location

Tanjung Murawa $=1$

Bangun Purba $=0$

$\mu=$ stochastic disturbance term

Regression coefficient was estimated with Ordinary Least Square (OLS) methods. Then it was tested using the value of R-squared, F-test and t-test (Gujarati, 2003).

\section{RESULTS AND DISCUSSION}

Small ruminants in Deli Serdang Regency are local goat and sheep. In this research, farmer had 18 to 24 heads of goat or sheep that was more than Devendra (2012) stated that the farmers in developing countries usually have 2-10 heads of small ruminants.

Composition of small ruminants' ownership indicated heterogenity in livestock status. Rearing young female was due to farmer sold kid or unproductively doe, while young female was prepared to be doe/ewe (Table 1).

Performance goat and sheep reproduction is presented in Table 2 . The mating system both in goat and sheep were natural mating. Age of first kidding or lambing tended to similar ranging from
13 to14 months.

Factors influencing goat and sheep maintenance of productivity in two research area were found using multiple regression model with Ordinary Least Square (OLS). The combination of the independent variable (doe/ewe, kidding/lambing interval, litter size, mortality, feed from palm and intercropping forage, small ruminants type and location) accounted for $82.37 \%$ variation in total output, in which the adjusted $\mathrm{R}^{2}$ was 0.8103 (Table 3 ). The results showed there was relationships among variables $(\mathrm{F}=61.39 ; \mathrm{P}<0.01)$. The doe/ewe could still be improved. Deli Serdang Regency needs to get attention from the Government in order to increase the population of small ruminants. On the other hand farmers need to be directed to increase quality and small ruminants weight to meet the market demand.

Simon (2006) showed that the main components of the integration between goat and palm plant were the oil palm trees, vegetation cover the trees, processing plant of palm oil bunch and the goat. Livestock type was the most significant and potent contributed to the total output $(\mathrm{t}=5.46 ; \mathrm{P}<0.01)$. Sheep-oil palm is more worthy than the goat-palm based on eligibility criteria being measured. In Deli Serdang Regency the farmers tended to prefer keep sheep from goats because goats are more susceptible to

Table 1. Composition of Goat and Sheep Ownership

\begin{tabular}{|c|c|c|c|c|c|c|c|c|}
\hline \multirow{3}{*}{ Animal } & \multicolumn{4}{|c|}{ Tanjung Murawa District } & \multicolumn{4}{|c|}{ Bangun Purba District } \\
\hline & \multicolumn{2}{|c|}{ Goat } & \multicolumn{2}{|c|}{ Sheep } & \multicolumn{2}{|c|}{ Goat } & \multicolumn{2}{|c|}{ Sheep } \\
\hline & Head & $\mathrm{AU}$ & Head & $\mathrm{AU}$ & Head & $\mathrm{AU}$ & Head & AU \\
\hline $\begin{array}{l}\text { Adult } \\
\text { Female }\end{array}$ & $6.16 \pm 2.73$ & $0.86 \pm 0.38$ & $6.08 \pm 3.52$ & $0.85 \pm 0.49$ & $10.48 \pm 6.84$ & $1.49 \pm 0.94$ & $4.24 \pm 3.33$ & $0.59 \pm 0.46$ \\
\hline $\begin{array}{l}\text { Adult } \\
\text { Male }\end{array}$ & $2.04 \pm 1.45$ & $0.28 \pm 0.20$ & $2.04 \pm 1.24$ & $0.28 \pm 0.17$ & $2.00 \pm 0.81$ & $0.28 \pm 0.11$ & $1.72 \pm 2.18$ & $0.24 \pm 0.30$ \\
\hline $\begin{array}{l}\text { Young } \\
\text { Female }\end{array}$ & $5.44 \pm 3.81$ & $0.38 \pm 0.26$ & $7.08 \pm 3.41$ & $0.49 \pm 0.23$ & $6.68 \pm 3.68$ & $0.46 \pm 0.25$ & $2.64 \pm 1.87$ & $0.18 \pm 0.08$ \\
\hline $\begin{array}{l}\mathrm{Kid} / \\
\text { Lamb }\end{array}$ & $5.04 \pm 2.92$ & $0.17 \pm 0.10$ & $5.40 \pm 2.41$ & $0.18 \pm 0.08$ & $5.52 \pm 3.75$ & $0.19 \pm 0.13$ & $2.20 \pm 0.96$ & $0.07 \pm 0.03$ \\
\hline Total & $18.68 \pm 8.42$ & $1.70 \pm 0.74$ & $20.60 \pm 7.57$ & $1.82 \pm 0.71$ & $23.80 \pm 11.84$ & $2.43 \pm 1.14$ & $10.28 \pm 4.93$ & $1.04 \pm 0.57$ \\
\hline
\end{tabular}

$\mathrm{AU}=$ Animal Unit; Male and female of goat or sheep $( \pm 2$ year $)=0.14 \mathrm{AU}$; Young male and female $(6$ to 8 months $)=0.07 \mathrm{AU}$; Kid or Lamb (1 to 3 months $)=0.035 \mathrm{AU}$ 
Table 2. Performance of Goat and Sheep Reproduction

\begin{tabular}{lccccc}
\hline \multirow{2}{*}{ Component } & \multicolumn{2}{c}{ Tanjung Murawa District } & & \multicolumn{2}{c}{ Bangun Purba District } \\
\cline { 2 - 3 } \cline { 5 - 6 } & Goat & Sheep & & Goat & Sheep \\
\hline Mating method & Natural & Natural & & Natural & Natural \\
Age of first kidding or lambing (month) & 14.00 & 13.00 & & 13.00 & 13.00 \\
Kiding or lambing interval (month) & 7.00 & 6.50 & & 7.60 & 7.00 \\
Age limit of raising (years) & & & & \\
$\quad$ Male & 2.00 & 3.00 & & 3.18 & \\
$\quad$ Doe & 4.00 & 4.00 & & 3.84 & 4.00 \\
Age of first mating (months) & & & & & \\
$\quad$ Male & 10.00 & 8.00 & & 11.00 & 8.00 \\
$\quad$ Female & 12.00 & 10.00 & & 9.00 & 7.00 \\
Litter size (heads) & 1.55 & 1.34 & & 1.50 & 1.34 \\
\hline
\end{tabular}

Table 3. Regression Analysis Factors that Influence to Increase Small Ruminants Productivity

\begin{tabular}{lrrrr}
\hline \multicolumn{1}{c}{ Components } & B & Std. Error & \multicolumn{1}{c}{$\mathrm{t}$} & \multicolumn{1}{c}{ Sig. } \\
\hline (Constant) & 0.733649 & 0.499964 & 1.467404 & 0.1457 \\
Number of doe/ewe (X1) & 0.333407 & 0.082152 & $4.058411^{* * *}$ & 0.0001 \\
Kidding/lambing interval (X2) & 0.187043 & 0.196679 & 0.951005 & 0.3441 \\
Litter Size (X3) & -0.452458 & 0.275561 & -1.641954 & 0.1040 \\
Mortality (X4) & -0.092014 & 0.085238 & -1.079495 & 0.2832 \\
Feed from oil palm and intercropped plant (X5) & 0.525090 & 0.107273 & $4.894901^{* * *}$ & 0.0000 \\
Livestock type (D1) & -0.371118 & 0.067854 & $-5.469325^{* * *}$ & 0.0000 \\
Location (D2) & 0.164170 & 0.046291 & $3.546526^{* * *}$ & 0.0006 \\
R-squared & & & & 0.823674 \\
Adjusted R-squared & & & & 0.810268 \\
F-statistic & & & & 61.39437 \\
\hline
\end{tabular}

*** Level of significance was $99 \%(\mathrm{P}<0.01)$

disease and can damage immature plant. On the contrary to the research of Ugwu (2012), 53\% of the farmers in Nigeria showed preference for goats and $47 \%$ for sheep. Thus, goat appears to be more favoured than sheep because of its adaptability to the environment. Saico and Abul (2007) stated that small ruminants particularly goats can sustain under a diverse climatic condition. According to Owusu (2012), the cover vegetation obviously serves as a good fodder that could support livestock. Keeping livestock under perennial cropps is a familiar practice in tropical and sub-tropical areas of the world. Mayulu et al. (2013) founded that by product produced from plantation and palm oil mill can be utilized for energy and protein source of ruminant feed. The 
use of Fermented Palm Oil Fronds (FPOF) in a complete feed could improve performance and meat quality of goat (Musnandar et al.., 2011). The availability of the land area of 234 ha in Tanjung Morawa was able to accommodate a total of 3,276 heads, while in the Bangun Purba with an area of 180 ha can accommodate as many as 2,520 small ruminants.

Manure production of adult goat/sheep was $240 \mathrm{~g}$ of dry matter/head/day in which it consisted of feces and urine. With assumption that compost from $100 \%$ livestock manure, then the availability of goat manure in Tanjung Morawa was 40,909.2 $\mathrm{kg} / \mathrm{h}$ ead/year, while for sheep it was 52,122 $\mathrm{kg} /$ head/year. In Bangun Purba District, the availability of goat manure was 22.513 $\mathrm{kg} / \mathrm{h}$ ead/year, while for sheep was 45.114 $\mathrm{kg} / \mathrm{head} /$ year.

Fertilizer requirement for palm plant was 20 $\mathrm{kg} /$ tree/year. There were 12,125 palm trees in Tanjung Morawa District and 10,000 trees in Bangun Purba District. In Tanjung Morawa District production of goat manure can only fertilize 2,045 trees (16.86\%), and sheep manure may fertilize 2,606 oil palm trees $(21.49 \%)$. In Bangun Purba District, goat manure could fertilize 1,126 trees (11.26\%) and sheep manure may fertilize 2,256 trees $(22.56 \%)$. The program of increasing the economic potential of integrating goat and palm tree need investments from major public agricultural research (governments, universities and non-profit agencies) and private sector (Devendra, 2012; Uka, 2008). Uthai (2011) stated that the three cooperation among The Suwanvajukkasit Animal Research and Development Institute (SARDI), Kasetsart University (KU) and Bank of Agriculture and Agricultural Cooperatives (BAAC) had successfully promoted a national program of using animal farm waste for economic crop yield improvement in integrated animal-plant agriculture system. Other side, integrated farming is economically and environmentally, the motivation for integration would appear to be the national policy of diversification of production in Bangladesh (Shamim et al., 2011).

\section{CONCLUSION}

The contributions of manure in Tanjung Morawa and Bangun Purba to fertilize palm trees were $16.86 \%$ and $11.26 \%$ from goats and $21.49 \%$ and $22.56 \%$ from sheep. Therefore, it was necessary to increase population of small ruminants in order to provide manure. It may be done by establishing partnership with investor, local government, animal of science office and private company. Technology and diversification of production would appear to be a policy in integrated farming system.

\section{REFERENCES}

Dinas Pertanian. 2012. Deli Serdang Dalam Angka Tahun 2012. Dinas Pertanian Kabupaten Deli Serdang.

Dinas Pertanian. 2013. Deli Serdang Dalam Angka Tahun 2013. Dinas Pertanian Kabupaten Deli Serdang.

Devendra, C. 2012. Intensification of integrated natural resources use and agricultural systems in the developing world. Agrotechnol. 1(1):1-4

Gujarati, D.N. 2003. Basic Econometrics. Fourth Edition. Published by McGraw-Hill Printed in Singapore.

Gunawan and A. Sulastiyah. 2010. Pengembangan usaha peternakan sapi melalui pola integrasi tanaman ternak dan pembangunan kawasan peternakan. Jurnal Ilmu-Ilmu Pertanian. 6(2):157-168

Manurung, B.P. 2004. Sistem Integrasi Kelapa Sawit Model Agricinal (Siska). PT Agricinal Bengkulu.

Mayulu H, C.I. Sutrisno, Sunarso, Sumarsono, M. Christiyanto and K. Kharyudono. 2013. Potency of palm oil plantation and mill by product as ruminants feed in Paser regency, East Kalimantan. Int. J. Sci. Eng. 5(2):56-60

Musnandar, E, A. Hamidah and R.A. Muthalib. 2011. The effect of fermented oil palm fronds in diet on body weight gain and meat quality of goat. J. Indonesian Trop.Anim. Agric. 36(2):120-125

Owusu E., G. C. Clerk and J. K. Mensah. 2012. Effect of dung of goat in oil palm plantations on the growth of soil facultative parasite sclerotium rolfsii. sacc. Int. J Plant. Anim. Env. Sci. 2(1):202-208

Saico, S. S. and S. Abul. 2007. Socio-economic constraints on goat farming in the Lowveld of Swaziland. A Case Study of Matsanjeni. J. Sustain. Dev. Afr. 9(3):37-49

Shamim, A.M., F. Nusrat and M.R. Debi. 2011. Integrated Farming System : Prospects in Bangladesh . J. Environ. Sci. Natural Resources. 4(2):127-136

Simon P. G. 2006. Pengembangan Sistem 
Integrasi Usaha Ternak Kambing dengan Perkebunan Kelapa Sawit : Kajian Berdasarkan Ketersediaan Pakan dan Kebutuhan Nutrisi. Wartazoa. 16(2):53-64 Singarimbun, M and S. Effendi. 1995. Metode Penelitian Survey. LP3S. Jakarta.

Soedjana, T. D. 2007. Sistem Usaha tani terintegrasi tanaman-ternak sebagai respons petani terhadap faktor resiko. Jurnal Litbang Pertanian. 26(2):87-87

Uka, K. 2008. Inovasi teknologi peternakan dalam sistem integrasi tanaman-ternak untuk menunjang swasembada daging sapi. Pengembangan Inovasi Pertanian. 1(3):189205

Ugwu, D.S. 2007. The role of small ruminants in the household economy of southeast zone of Nigeria. Res. J. Applied Sci. 2(6):726-732

Uthai, K. 2011. An integrated animal-plant agriculture system in Thailand in response to climate change. J. International Society for the Advancement of Spine Surgery. 17(1):816 